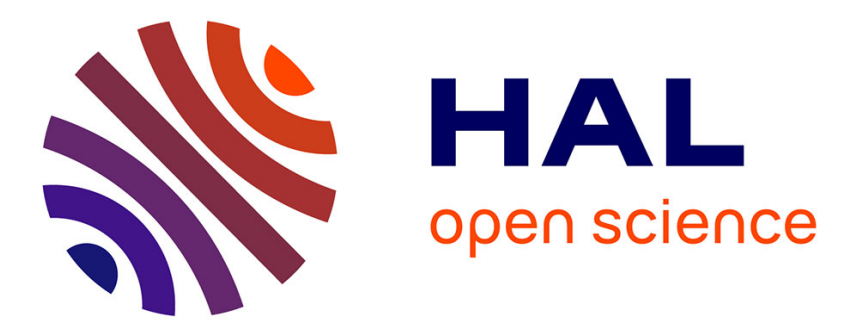

\title{
Solar photovoltaic powered on-site ammonia production for nitrogen fertilization
}

Z. Du, D. Denkenberger, J.M. Pearce

\section{To cite this version:}

Z. Du, D. Denkenberger, J.M. Pearce. Solar photovoltaic powered on-site ammonia production for nitrogen fertilization. Solar Energy, 2015, 122, pp.562-568. 10.1016/j.solener.2015.09.035 . hal02113576

\section{HAL Id: hal-02113576 \\ https://hal.science/hal-02113576}

Submitted on 29 Apr 2019

HAL is a multi-disciplinary open access archive for the deposit and dissemination of scientific research documents, whether they are published or not. The documents may come from teaching and research institutions in France or abroad, or from public or private research centers.
L'archive ouverte pluridisciplinaire HAL, est destinée au dépôt et à la diffusion de documents scientifiques de niveau recherche, publiés ou non, émanant des établissements d'enseignement et de recherche français ou étrangers, des laboratoires publics ou privés. 
Preprint of: Z. Du, D. Denkenberger, J.M. Pearce, Solar photovoltaic powered on-site ammonia production for nitrogen fertilization, Solar Energy 122, 562568 (2015). http://dx.doi.org/10.1016/j.solener.2015.09.035

\title{
Solar Photovoltaic Powered On-Site Ammonia Production for Nitrogen Fertilization
}

\author{
Z. Du ${ }^{\mathrm{a}}$, D. Denkenberger ${ }^{\mathrm{b}}$ and J.M. Pearce ${ }^{\mathrm{a}, \mathrm{c}, *}$ \\ a Department of Electrical \& Computer Engineering, Michigan Technological University, 1400 \\ Townsend Drive; Houghton, MI 49931, USA \\ b Denkenberger Inventing and Consulting, LLC 2345 Forest Ave.; Durango, CO 81301, USA \\ ${ }^{\mathrm{c}}$ Department of Materials Science \& Engineering, Michigan Technological University, 1400 Townsend \\ Drive; Houghton, MI 49931, USA \\ * Contact author: \\ 1400 Townsend Drive \\ Houghton, MI 49931-1295 \\ 906-487-1466 \\ pearce@mtu.edu
}

\begin{abstract}
Ammonia synthesis is the most important step for nitrogen-fertilizer production and consumes approximately $1 \%$ of the world's energy production and energy-related greenhouse gas emissions. In addition to the concomitant emissions caused by ammonia and nitrogen fertilizer synthesis, centrally produced fertilizer that must be distributed to farms also harms the environment because of the embodied energy of transportation. An environmentally-optimal nitrogen fertilizer system would be distributed on farms themselves using only renewable inputs. Recent developments in solar photovoltaic technology and subsystems for ammonia production have made non-organic on-site ammonia production physically possible. This study provides a technical evaluation of the process for on-site nitrogen-fertilization of corn using solar photovoltaic electricity as the energy input. The system consists of a water electrolysis system to generate hydrogen and a membrane system to generate nitrogen needed as material inputs. Total power consumption for syngas preparation to generate a unit of ammonia is calculated. System total energy consumption is calculated while compensating syngas preparation with heat recovery. Five case-study locations are evaluated to determine their suggested nitrogen fertilizer addition (N-rate) for corn growth and the energy consumption for suggested N-rate is calculated. The System Advisor Model (SAM) is then used to simulate the PV system output for those five locations. Finally, the PV land use required as a fraction of the corn field area is determined. The results indicate that because PV is so much more efficient at solar energy conversion than organic methods, even the worst case evaluated in Indiana requires less than $1 \%$ of the corn field converted to a PV system to provide enough energy to generate sufficient amounts of ammonia for fertilizer for the remaining corn. The system was modeled to provide ammonia to fertilize for corn fields larger than 1079 acres with the worst soil conditions, the area of which applies to more than half of cropland in the U.S. in 2011. As the finiteness and emissions of fossil fuel production of nitrogen become more important, this renewable system should become economical and future investigations into its overall viability are warranted.
\end{abstract}


Preprint of: Z. Du, D. Denkenberger, J.M. Pearce, Solar photovoltaic powered on-site ammonia production for nitrogen fertilization, Solar Energy 122, 562-

568 (2015). http://dx.doi.org/10.1016/j.solener.2015.09.035

\section{Keywords}

Photovoltaic; Ammonia; Corn; Fertilizer; Electrolysis; Distributed generation; Distributed production

\section{Introduction}

Ammonia synthesis is the most important step for nitrogen-fertilizer production and consumes $1 \%$ of the world's energy production and resultant energy-related greenhouse gas emissions (Kitano et al., 1995). Ammonia consists only of nitrogen and hydrogen. Both hydrogen and nitrogen are widely available in earth's atmosphere, but currently, according to U.S. Environmental Protection Agency (EPA) natural gas is used as a primary hydrogen generation source, and this process results in carbon dioxide $\left(\mathrm{CO}_{2}\right)$ emissions (EPA, 2009). Carbon dioxide emissions have well-known environmental problems and there are efforts underway to replace fossil fuels with renewable sources of energy (Flavin, 1990; Steinberg, 1999; El-Fadel et al., 2003; Sims, 2004; Stern, 2006; Granovskii et al., 2007; Tsoutsos et al., 2008). In addition to the emissions caused by ammonia and nitrogen fertilizer synthesis, there are also negative environmental externalities caused by the transportation of the centrally produced good to distributed farms (Brentrup et al., 2004; Horvath, 2006; Facanha and Horvath, 2007; Pearce et al., 2007). Thus the environmentally optimal nitrogen fertilizer system would be distributed on farms themselves using only renewable inputs. Historically, the only means of doing this was with natural nitrogen fixation following the practices used by organic farmers (Havlin, et al. 1990; Drinkwater, et al. ,1998; Badgley, et al., 2007). Unfortunately, this process has a significant productivity penalty with nonproductive (or less than optimal) crop rotations and potentially lower than optimal nitrogen levels. However, the nitrogen and hydrogen needed for ammonia synthesis can be obtained by using an air membrane system and water electrolysis, respectively. Commercial water electrolyzers can reach energy efficiency (higher heating value) as high as 73\% (Ivy, 2004), making them feasible for hydrogen generation. Both of these methods-membrane and water electrolysis have the potential to be environmentally friendly as they use renewable natural resources as inputs (air and water); however, the sustainability is dependent on the energy used to run the processes. Solar photovoltaic (PV) technology, which converts renewable solar energy directly into electricity is a longestablished sustainable energy technology (Pearce, 2002). As solar energy is available in all agriculturally relevant geographic locations, it represents a prime candidate for a sustainable solution for powering a distributed system for nitrogen fertilizer ( $\mathrm{N}$-fertilizer) production.

According to the United States Department of Agriculture (USDA), corn consumed $45.67 \%$ of $\mathrm{N}$-fertilizer in United States in 2010 (USDA, 2013). Thus, corn fertilization in the United States is used as a case study here to determine the energetic feasibility for on-farm distributed $\mathrm{N}$-fertilizer production using solar-generated electricity. First, the required $\mathrm{N}$-fertilizer amounts are determined for five locations as the $\mathrm{N}$-rate for corn strongly depends on the soil condition, which is greatly influenced by weather conditions (Fernández et al., 2012). Then the total power consumption for syngas preparation to generate a unit of ammonia is calculated. System total energy consumption is calculated while using heat recovery with syngas preparation for suggested N-fertilizer amounts. The System Advisor Model (SAM) is then used to simulate the PV system output for those five locations. Finally, the PV land use required as a fraction of the corn field area is determined. The results are presented and the technical and energetic viability of distributed on-farm nitrogen-fertilizater production are discussed. 
Preprint of: Z. Du, D. Denkenberger, J.M. Pearce, Solar photovoltaic powered on-site ammonia production for nitrogen fertilization, Solar Energy 122, 562568 (2015). http://dx.doi.org/10.1016/j.solener.2015.09.035

\section{Methods}

The proposed ammonia generation system is shown in Figure 1. The nitrogen membrane generator (2) works with the air compressor (1) to generate nitrogen, using air as source material. Hydrogen is generated from the water electrolyzer system (3). Hydrogen and nitrogen gases are then compressed and heated as syngas, which is combined in the ammonia converter (6). The heat generated in the converter will be recovered either to electrical energy or thermal energy, unconverted syngas will also be separated from ammonia and recycled as syngas again. 
Preprint of: Z. Du, D. Denkenberger, J.M. Pearce, Solar photovoltaic powered on-site ammonia production for nitrogen fertilization, Solar Energy 122, 562568 (2015). http://dx.doi.org/10.1016/j.solener.2015.09.035

1 Air compressor

2 Nitrogen membrane system

3 Water electrolyzer

4 Syngas compressor

5 Syngas heater

6 Ammonia converter

7 Heat recovery system

8 Gas recovery system

9 PV power line

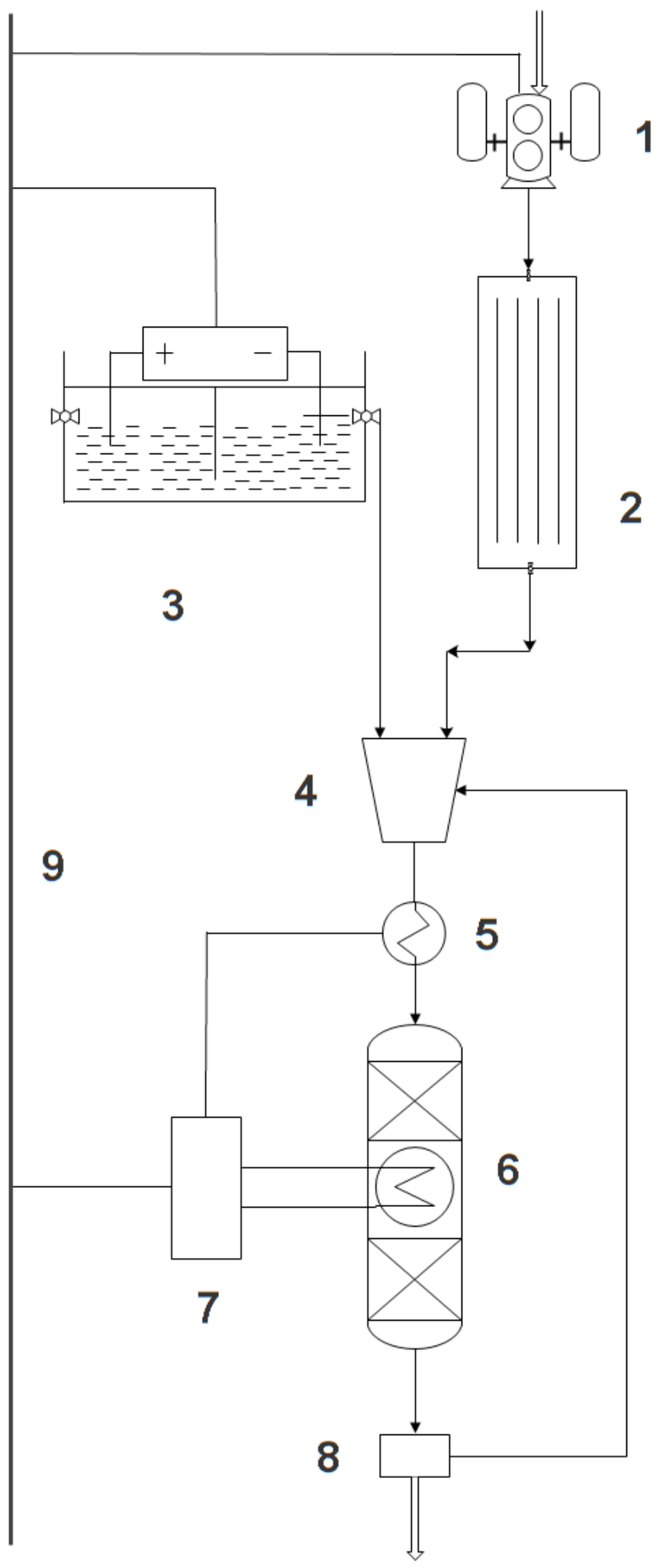


Preprint of: Z. Du, D. Denkenberger, J.M. Pearce, Solar photovoltaic powered on-site ammonia production for nitrogen fertilization, Solar Energy 122, 562568 (2015). http://dx.doi.org/10.1016/j.solener.2015.09.035

Figure 1. System diagram

The ammonia synthesis conversion rate is limited by temperature. Industrially the temperature used to speed up reaction is usually around $400^{\circ} \mathrm{C}$ to $500^{\circ} \mathrm{C}$ and the conversion rate is around $10 \%$ to $15 \%$ at this temperature (Lovell, 1980). However, unconverted syngas can be recovered, so the total conversion rate can eventually reach 97\% (Barclay and Leigh, 2000). The primary criteria for selecting sub-components of the system was to achieve maximum energy efficiency.

\subsection{Water electrolysis}

To produce $1 \mathrm{lb}(0.45 \mathrm{~kg})$ of ammonia, $0.08 \mathrm{~kg}$ hydrogen needs to be produced. The Stuart IMET 1000 Series (Ivy, 2004) electrolyzer was selected as it generates hydrogen with purity higher than $99.997 \%$. The energy consumption rate is $4.80 \mathrm{kWh} / \mathrm{Nm}^{3}$ (N is "normal" in this context). This $0.08 \mathrm{~kg}$ of hydrogen is produced under a pressure of $360 \mathrm{psig.} 4.43 \mathrm{kWh}$ of electrical energy will be consumed to produce this amount of hydrogen.

\subsection{Nitrogen membrane generator}

An IGS Skidded Nitrogen Generators 7000 Series (IGS Generon, 2010) was selected, which produces nitrogen with a purity of $99.9 \%$. With an inlet gas-flow rate of 129 ACFM (actual cubic feet per minute) under $100 \mathrm{psig}$, the nitrogen generator yields nitrogen at rate of 60.2 ACFM under 100 psig. This nitrogen generator itself requires no energy to operate, so the energy necessary to produce nitrogen depends on the power of an air compressor for the membrane system inlet gas. The FS-Circuit SE30 (Curtis-Toledo, INC., 2013) is a commercial gas compressor. To compress air to 100 psig at a flow rate of 129 ACFM, the air compressor works at $22.37 \mathrm{~kW}$. The nitrogen consumption rate is given by:

$\mathrm{E}_{\mathrm{N}}=\left(\mathrm{V}_{\mathrm{N}} / \mathrm{Q}_{\mathrm{N}}\right) \times \mathrm{P}_{\mathrm{N}}$

Where $\mathrm{V}_{\mathrm{N}}$ is volume of nitrogen, $\mathrm{Q}_{\mathrm{N}}$ is generation rate of membrane system, $\mathrm{P}_{\mathrm{N}}$ is power consumption of air compressor. Each pound of ammonia requires $0.38 \mathrm{~kg}$ of nitrogen in syngas at $97 \%$ conversion rate, which is 11.691 cubic feet at $0^{\circ} \mathrm{C}$ under $1 \mathrm{~atm}$. Using equation (1), for the membrane system to generate this much nitrogen, the compressor consumes $0.130 \mathrm{kWh}$ energy.

\subsection{Ammonia synthesis}

Conventional industry produces ammonia based on the Haber-Bosch method; the reaction equation is:

$0.5 \mathrm{~N}_{2}+1.5 \mathrm{H}_{2}=\mathrm{NH}_{3} ; \Delta \mathrm{H}=-46 \mathrm{~kJ} / \mathrm{mol}$

This is an exothermic reaction. At standard enthalpy, every pound of ammonia produced generates $0.340 \mathrm{kWh}$ of thermal energy. The ammonia converter is usually operated at $400^{\circ} \mathrm{C}$ to $500^{\circ} \mathrm{C}$ under 140 to $210 \mathrm{~atm}$; this is not the condition for standard enthalpy. However, syngas is close to standard enthalpy condition $\left(25^{\circ} \mathrm{C}, 1 \mathrm{~atm}\right)$ before being compressed to required pressure and heated to conversion temperature. Upon application (after cooling from heat recovery), the generated ammonia will also be close to standard enthalpy conditions. According to Hess's law of constant heat summation, the total generated heat can be estimated as $0.340 \mathrm{kWh}$ from the production of $0.45 \mathrm{~kg}$ of ammonia. The nitrogen required to produce $0.45 \mathrm{~kg}$ of ammonia is $0.37 \mathrm{~kg}$; thus, the total energy $\mathrm{E}(\mathrm{kWh})$ required to produce $0.45 \mathrm{~kg}$ of $\mathrm{N}$ can be given as:

$\mathrm{E}=\left(\mathrm{E}_{\text {syngas }}-\eta \times \mathrm{E}_{\text {exo }}\right) / 0.822$ 
Preprint of: Z. Du, D. Denkenberger, J.M. Pearce, Solar photovoltaic powered on-site ammonia production for nitrogen fertilization, Solar Energy 122, 562568 (2015). http://dx.doi.org/10.1016/j.solener.2015.09.035

Where $E_{\text {syngas }}(\mathrm{kWh})$ is the energy required to produce the correspondant hydrogen and nitrogen, $\eta$ is the total converter heat recovery rate. $\mathrm{E}_{\text {exo }}(\mathrm{kWh})$ is the standard enthalpy to produce $0.45 \mathrm{~kg}$ of ammonia. 0.822 is nitrogen mass fraction in ammonia.

\subsection{Case Study}

For Indiana, a major corn-producing state in the United States, the suggested N-rate for corn growth is given directly for five different regions (Camberato and Nielsen, 2015). Therefore, a location was chosen in each of five regions in order to determine the N-rate for corn growth. Table 1 shows the results.

Table 1. N-rate for five locations

\begin{tabular}{|c|c|c|}
\hline Location & Indiana Region & N-rate (kg/hectare) \\
\hline Evansville & Southwest (SW) & 205 \\
\hline Grissom & North Central (NC) & 212 \\
\hline Indianapolis & Central (C) & 247 \\
\hline Fort Wayne & Northeast (NE) & 254 \\
\hline Delaware & East Central (EC) & 262 \\
\hline
\end{tabular}

The suggested N-rate R is also given in a formula by soil conditions (Shapiro et al., 2008):

$\mathrm{R}=35+(1.2 \times \mathrm{E})-(8 \times \mathrm{N})-(0.14 \times \mathrm{E} \times \mathrm{O})-\mathrm{C}$

For this equation, $\mathrm{E}$ is the expected yield (bu/ac), $\mathrm{N}$ is the nitrate ppm in soil, $\mathrm{O}$ is the percentage of organic matter in soil, $\mathrm{C}$ accounts for $\mathrm{N}$ from all other sources in the current soil (lb./ac). According to this formula, suggested N-rate can range from $0 \mathrm{~kg} / \mathrm{ha}$ to $353 \mathrm{~kg} / \mathrm{ha}$. It is known that, while more Nfertilizer is applied in greater quantities than suggested $\mathrm{N}$-rate, there will be no additional increase in yield (Camberato and Nielsen, 2014). Thus, $353 \mathrm{~kg} /$ ha could be used to estimate the maximum N-rate for any expected yield.

\subsection{PV system simulation}

The National Renewable Energy Lab's System Advisor Model (SAM 2014.1.14) is used for simulation of the PV systems. The systems are simulated in the same five locations where the $\mathrm{N}$ rates are determined as listed in Table 1. PV modules (Suntech Power STP310-24/Vdx) with a nominal efficiency of $16 \%$ were chosen for all five locations. The arrays are designed to provide output of 200 $\mathrm{kW}$ dc. With inverter efficiency of $96.32 \%$, the array provides a capacity of $448 \mathrm{~kW}$ per ha of total land area. According to this simulation, Table 2 shows the PV system energy/land rates for the five casestudy locations. The total module area is $1,250 \mathrm{~m}^{2}$, with 645 modules. Arrays have ground coverage ratio (GCR) of 0.3 . At this configuration, arrays occupy total area of 1 acre ( $0.4 \mathrm{ha})$. Since PV modules degrade with time, the examination covers both the 1st- and 25th-year energy rates at degration rate of $0.5 \%$ per year.

Table 2. Annual energy generation from PV system 
Preprint of: Z. Du, D. Denkenberger, J.M. Pearce, Solar photovoltaic powered on-site ammonia production for nitrogen fertilization, Solar Energy 122, 562568 (2015). http://dx.doi.org/10.1016/j.solener.2015.09.035

\begin{tabular}{|c|c|c|}
\hline Location & \multicolumn{2}{|c|}{ PV energy rate (kWh/ac) } \\
\hline & $\mathbf{1}^{\text {st }}$ year & $\mathbf{2 5}^{\text {th }}$ year \\
\hline Evansville & 280,000 & 250,000 \\
\hline Grissom & 250,000 & 220,000 \\
\hline Indianapolis & 280,000 & 250,000 \\
\hline Fort Wayne & 270,000 & 240,000 \\
\hline Delaware & 250,000 & 220,000 \\
\hline
\end{tabular}

\section{Results}

\subsection{Required Energy as a Function of Heat Recovery}

Using equation 3, the energy consumed for generating each pound of $\mathrm{N}$ from ammonia with respect to heat recovery rate can be calculated; this is shown in Figure 2.

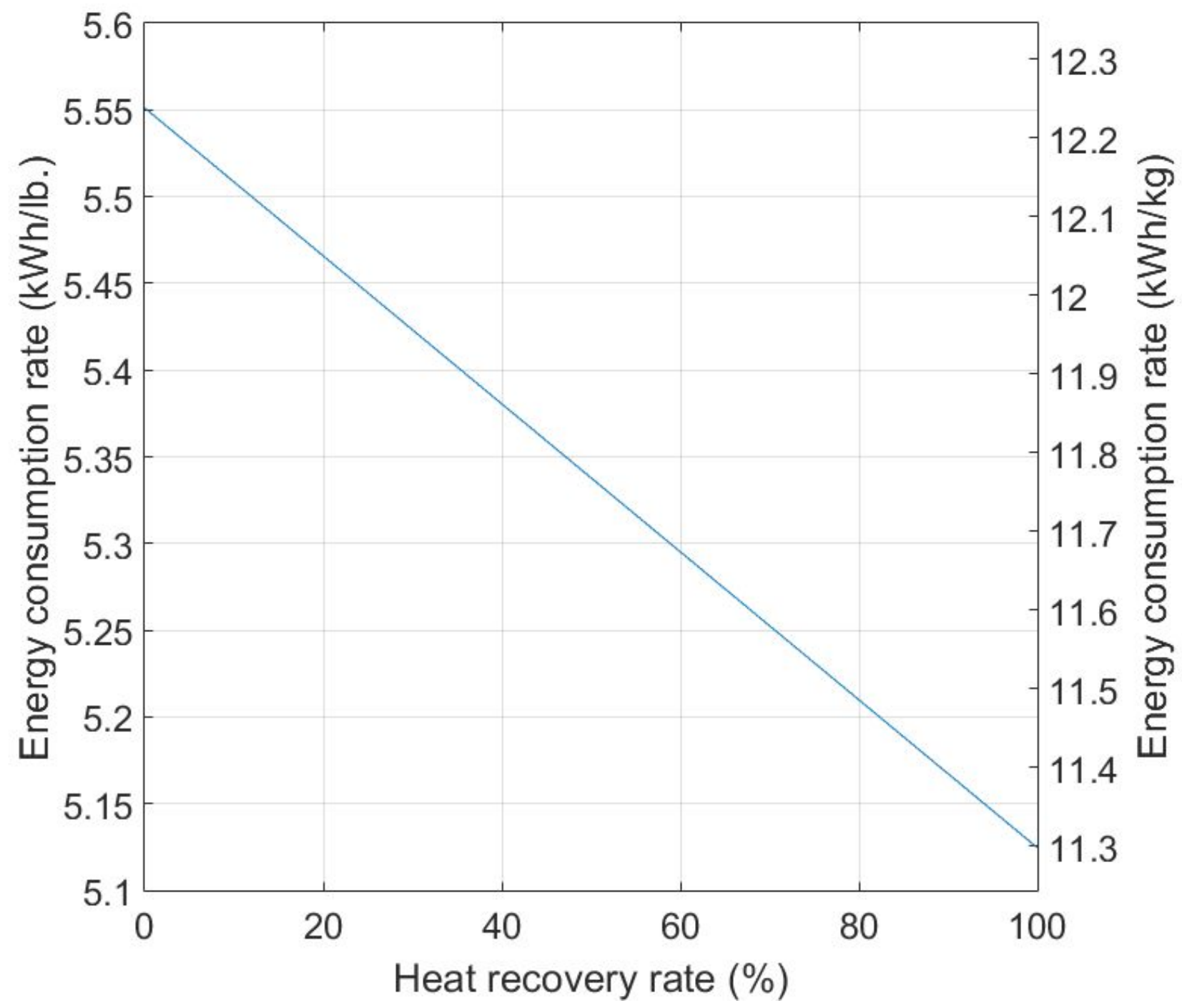

Figure 2. Energy consumption rate for unit N. Rate ranging from $5.12 \mathrm{kWh} / \mathrm{lb}(2.30 \mathrm{kWh} / \mathrm{kg})$ to 5.56 
Preprint of: Z. Du, D. Denkenberger, J.M. Pearce, Solar photovoltaic powered on-site ammonia production for nitrogen fertilization, Solar Energy 122, 562568 (2015). http://dx.doi.org/10.1016/j.solener.2015.09.035

$\mathrm{kWh} / \mathrm{lb}(2.50 \mathrm{kWh} / \mathrm{kg})$.

Thermal-electrical recovery rate is usually around $30 \%$, while thermal-thermal recovery rate is usually much higher, around $90 \%$. Any hybrid heat recovery system recovers heat to both thermal energy and electrical energy will have efficiency between $30 \%$ and $90 \%$, so it's necessary to examine energy rate in this interval. At heat recovery of $30 \%$, energy consumption rate is $2.46 \mathrm{kWh} / \mathrm{kg} \mathrm{N}$, while at $90 \%$, it lowers to $2.32 \mathrm{kWh} / \mathrm{kg} \mathrm{N}$.

\subsection{Annual Energy Consumption for $\mathbf{N}$ Fertilizer per Acre of Corn Field}

At a given heat recovery rate, an annual energy consumption per unit corn field is linear with its suggested N-rate. Figure 3 shows the results, regarding suggested N-rate ranging from $0 \mathrm{~kg} / \mathrm{ha}$ to 315 $354 \mathrm{~kg} / \mathrm{ha}$. Both results at heat recovery rate of $30 \%$ and $90 \%$ are given, hybrid recovery systems should provide a result between these two limits.

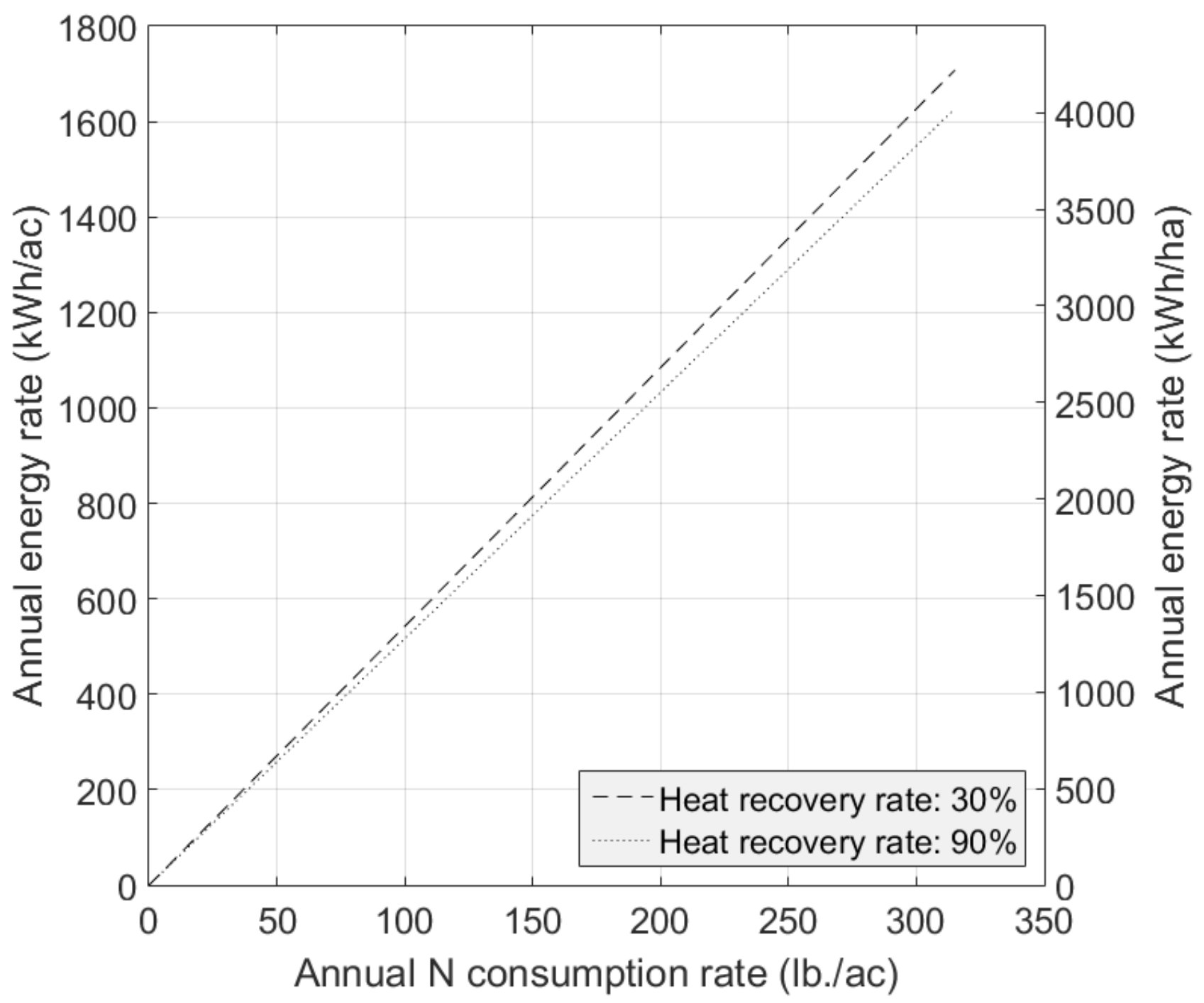


Preprint of: Z. Du, D. Denkenberger, J.M. Pearce, Solar photovoltaic powered on-site ammonia production for nitrogen fertilization, Solar Energy 122, 562568 (2015). http://dx.doi.org/10.1016/j.solener.2015.09.035

Figure 3. Annual energy consumption rate as a function of annual $\mathrm{N}$ consumption rate. At $0 \mathrm{kWh} / \mathrm{ac}$, there are high quantities of organic matter and nitrate concentrations in the soil with low yield expectation. At the highest yield expectation of 270 bushels/ac (16,700 kg/ha) and with the worst soil conditions and no organic matter nor nitrate, energy rate can reach as high as $14230 \mathrm{kWh} / \mathrm{ha}(30 \%$ recovery rate) or $4030 \mathrm{kWh} / \mathrm{ha}$ (90\% recovery rate).

For suggested $\mathrm{N}$ fertilizer rates at the five case-study locations, the energy rate per acre is calculated for a sensitivity between $30 \%$ and $90 \%$ heat recovery rates. Table 3 summarizes the results of this calculation.

Table 3. Energy consumption rates for adequate $\mathrm{N}$ fertilizer for case-study locations

\begin{tabular}{|c|c|c|}
\hline Location & $\begin{array}{c}\text { Energy Consumption Rate } \\
\text { (kWh/ha) }\end{array}$ \\
\hline & 30\% Heat Recovery Rate & $\mathbf{9 0 \%}$ Heat Recovery Rate \\
\hline Evansville & 2451 & 2335 \\
\hline Grissom & 2570 & 2437 \\
\hline Indianapolis & 2965 & 2817 \\
\hline Fort Wayne & 3039 & 2891 \\
\hline Delaware & 3114 & 2965 \\
\hline
\end{tabular}

\subsection{Land Required for Distributed N-Fertilizer Production with PV}

Dividing the energy consumption rate of each location by its corresponding PV system energy rate gives the land occupation. Figure 4 illustrates the results. To determine the worst case scenario the following assumptions were made: Of all five case-study locations, the PV system in Delaware yields the worst energy rate so this location was used. Then, the worst soil condition is assumed to be present in Delaware; therefore, the energy consumption rate is assumed to be $4230 \mathrm{kWh} / \mathrm{ha}$ (30\% recovery rate) or $4030 \mathrm{kWh} / \mathrm{ha}$ (90\% recovery rate).

At heat recovery rate of 30\% (shown in Figure 4.a), in 25 years, land of the PV in Evansville varies from $0.35 \%$ to $0.40 \%$, in Grissom from $0.41 \%$ to $0.46 \%$, in Indianapolis from $0.43 \%$ to $0.48 \%$, in Fort Wayne from $0.46 \%$ to $0.51 \%$, in Delaware from $0.51 \%$ to $0.57 \%$, and worst case land of the PV in Delaware varies from $0.70 \%$ to $0.78 \%$. 
Preprint of: Z. Du, D. Denkenberger, J.M. Pearce, Solar photovoltaic powered on-site ammonia production for nitrogen fertilization, Solar Energy 122, 562568 (2015). http://dx.doi.org/10.1016/j.solener.2015.09.035

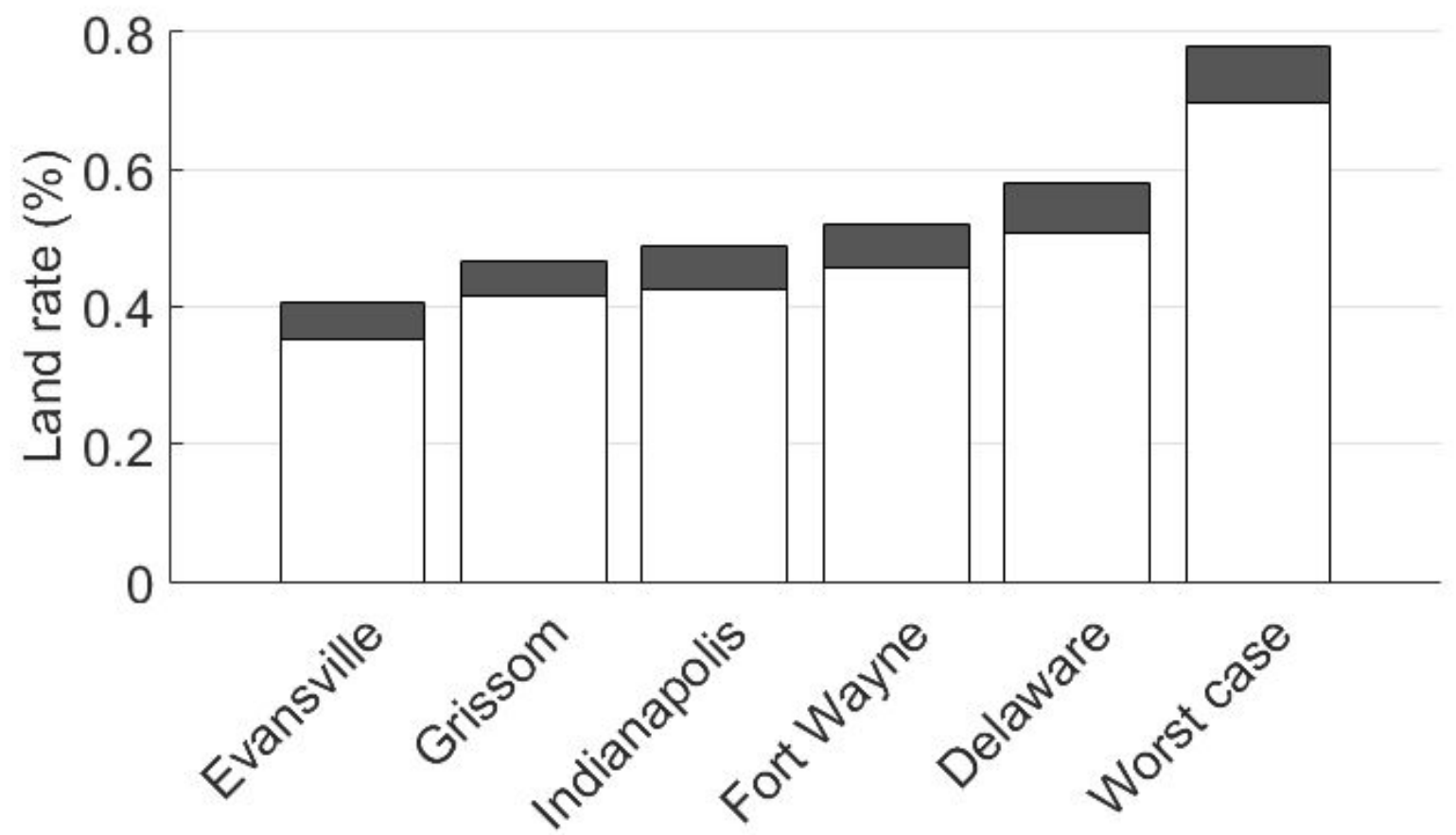

a.

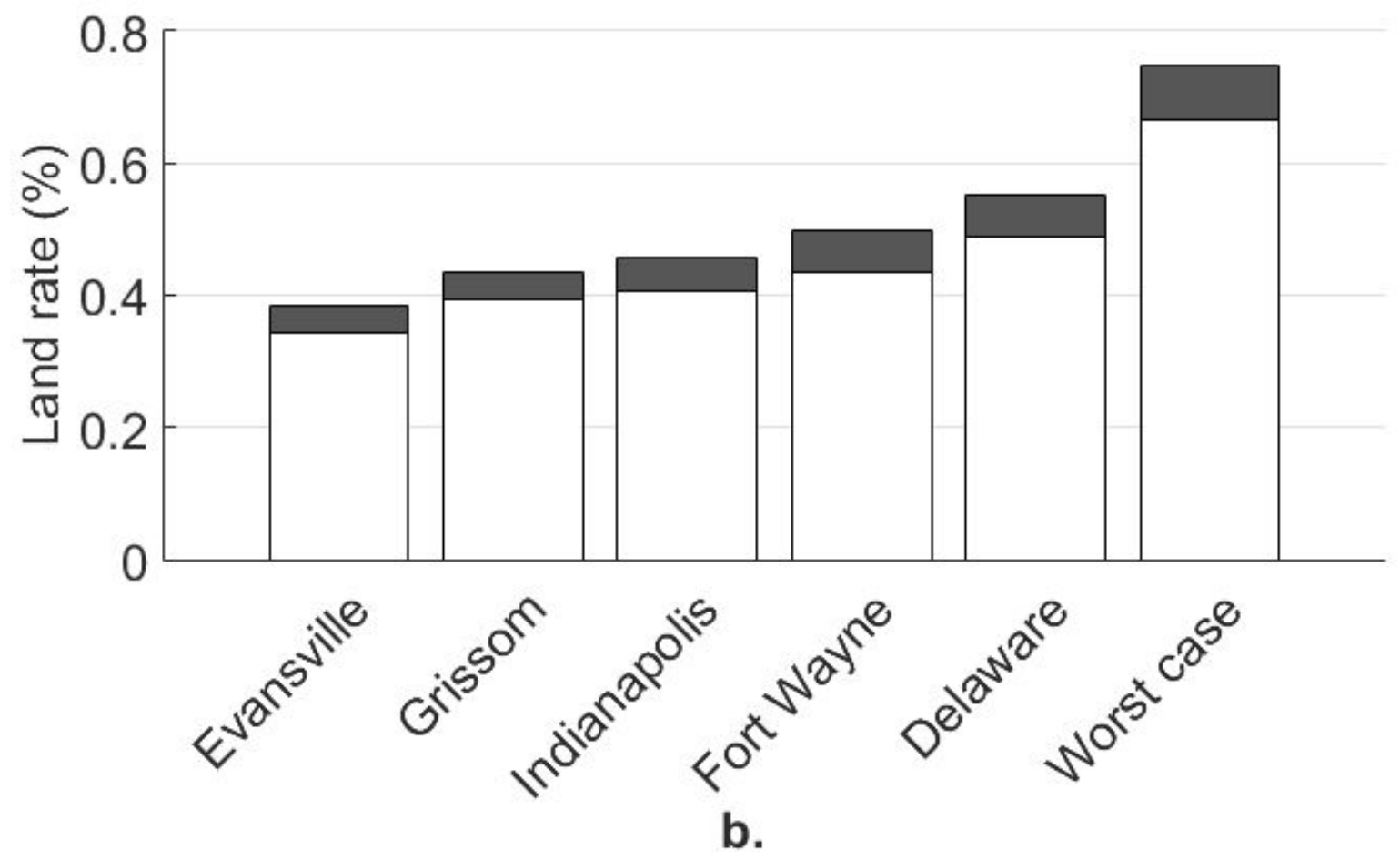

Figure 4. PV land usage after 25 years of degradation for systems with a) a heat recovery rate of $30 \%$ 
Preprint of: Z. Du, D. Denkenberger, J.M. Pearce, Solar photovoltaic powered on-site ammonia production for nitrogen fertilization, Solar Energy 122, 562568 (2015). http://dx.doi.org/10.1016/j.solener.2015.09.035

and b) a heat recovery rate of $90 \%$

At a heat recovery rate of 90\% (shown in Figure 4.b), in 25 years, the PV land usage in Evansville varies from $0.34 \%$ to $0.38 \%$, in Grissom from $0.39 \%$ to $0.43 \%$, in Indianapolis from $0.40 \%$ to $0.45 \%$, in Fort Wayne from $0.43 \%$ to $0.49 \%$, in Delaware from $0.48 \%$ to $0.55 \%$, and worst case PV land use in Delaware varies from $0.66 \%$ to $75 \%$. As can be seen from Figure 4, in all cases the land area necessary to provide the PV electricity for the necessary $\mathrm{N}$-fertilizer was less than $1 \%$ of the total. Thus, the land required for the solar photovoltaic collectors is significantly smaller penalty than organic techniques of producing nitrogen.

\section{Discussion and Future Work}

The results indicate that the systems are technically and energetically viable. As shown in Figure 4, even the worst case requires no more than $0.78 \%$ of the corn field to provide enough energy to generate sufficient amounts of ammonia for fertilizer. However, it should be pointed out that further experimentation is needed to verify these numbers as some factors in ammonia production, such as $\mathrm{CO}_{2}$ removal from syngas, may influence these results, potentially leading to lower yields. However, these factors will not significantly affect the energy consumption rate and the PV area needed. The feasiblilty of use PV system to provide energy for on-site ammonia production will still be viable. For shadetolerant crops, the PV panels may be able to be placed above the crops in "agrivoltaic systems" (Goetzberger and Zastrow, 1982; Marrou et al., 2013; Dinesh and Pearce, 2015), leading to even smaller impacts on the farming system.

Distributed production of nitrogen fertilizer may also be useful for directly reducing fertilizer effects on the environment. Farmers often over apply fertilizer. For example, in 2010, 31\% N-based fertilizer applied to corn was in excess of the suggested N-rate (Ribaudo et al., 2012). Over nitrogen fertilzation can contaminate groundwater and cause other environment problems (Power and Schepers 2003). A dedicated on-site ammonia production system, like the one proposed for the first time here, may efficiently help nitrogen management by producing just enough $\mathrm{N}$-fertilizer for a given area by design. As the farmers would also be the nitrogen fertilizer synthesizers it may lead more careful application and low-cost open-source nitrate testing equipment (Wittbrodt, et al., 2015) based off of open-source colorimeters and water testing apparatuses (Anzalone et al., 2013; Wijnen, et al., 2014). There is some evidence from related distributed production (e.g. with solar PV), that more environmentally responsible behavior is created simply by exposure to the green technology (Schelly, 2014a, 2014b); however, future field work is needed to see if such an effect would transfer to the farm community.

The technologies evaluated in this study are still on a relatively large scale. In this case, the commercial membrane system is able to generate nitrogen at $95 \mathrm{Nm}^{3} / \mathrm{hr}$, while the water eletrolyzer is able to generate hydrogen at $60 \mathrm{Nm}^{3} / \mathrm{hr}$. Since three times the volume of hydrogen is required as nitrogen (see equation 2), five hydrogen generators can be coupled with one nitrogen generator. Then the hydrogen generators could be run at $95 \%$ utilization. Working continuously, at conversion rate of $97 \%$, one set of these generators can provide syngas for ammonia to fertilize 436 ha of corn field that has the worst soil condition. Farms that have cropland area larger than 404 ha occupy 53.7\% of total U.S. croplands in 2011 (MacDonald et al., 2013). Research is needed in developing efficient sub-components with 
Preprint of: Z. Du, D. Denkenberger, J.M. Pearce, Solar photovoltaic powered on-site ammonia production for nitrogen fertilization, Solar Energy 122, 562568 (2015). http://dx.doi.org/10.1016/j.solener.2015.09.035

smaller throughputs. This could open up the technology to the other approximately half of farms in the U.S. Furthermore, this approach may work for smaller farms if they teamed up to share a system until the components are miniaturized.

To put the size of the PV system in perspective, on a 1000 acre (404 ha) farm, the PV array would take up less than 7.8 acres (3.2 ha) and produce more than $1.7 \mathrm{GWh}$ electrical energy. Energy wise, the proposed system can provide nitrogen an energy intensity of $2.32 \mathrm{kWh} / \mathrm{kg}$ to $2.46 \mathrm{kWh} / \mathrm{kg}$ ammonia; this is fairly competitive with modern industrial energy intensity of $1.40 \mathrm{kWh} / \mathrm{kg}$ (Schlögl, 2003). The land use of the equipment is likely to be much smaller than the PV.

The results of this study are promising and indicate a potential for the technology of distributed PVpowered nitrogen fertilizer production. However, this study is only the foundation of the needed work to develop this into a laterally scalable distributed farming system. Further, more granular studies are needed to examine the possibility of building experimental systems and a careful examination of the economic viability must be determined.

There are also technical challenges that must be addressed. First, industrial production requires a stable ammonia converter condition to maintain a high energy efficiency. However, for a PV system, maintaining continuous stable energy output is a challenge without storage. Additional energy storage systems and special energy distribution methods may be needed to maintain stable energy input. This may not be prohibitively expensive as not only has the levelized cost of PV-generated electricity dropped radically (Branker et al., 2011), but with recent advances at Tesla, battery costs have also declined sharply (Tesla, 2015). Second, all calculations in this paper are based on a commercial product since a specialized water electrolyzer or nitrogen generator for ammonia production is not available, and both selected generators produce gas above $1 \mathrm{~atm}$, which makes the energy efficiency lower. A recent study has shown an energy conversion rate (given by efficiency of PV system times energy efficiency of electrolysis) greater than $18 \%$ to produce hydrogen (Licht et al., 2001). This is much higher than the total hydrogen production energy conversion rate considered here of $12 \%$. Future work should investigate coupling these more efficient systems, as water electrolysis occupies $82 \%$ of the total energy consumption before heat recovery, improving its efficiency will greatly impact the overall system efficiency.

\section{Conclusions}

The results of this study indicate that it is technically feasible for nearly half of the agricultural area in the U.S. to have individual farms producing their own nitrogen fertilizer using direct solar energy with current technology that is already commercially available. The land required for the solar photovoltaic collectors is less than $1 \%$ of the total land area, a much significantly smaller penalty than organic techniques of producing nitrogen. As the finiteness and emissions of fossil fuel production of nitrogen become more important, this renewable system should become economical and future investigations into its overall viability are warranted. 
Preprint of: Z. Du, D. Denkenberger, J.M. Pearce, Solar photovoltaic powered on-site ammonia production for nitrogen fertilization, Solar Energy 122, 562568 (2015). http://dx.doi.org/10.1016/j.solener.2015.09.035

\section{Acknowledgments}

The authors would like to thank K. Noelker for helpful discussions.

\section{References}

Anzalone, G.C., Glover, A.G., Pearce, J.M., 2013. Open-Source Colorimeter. Sensors. 2013;13: 5338“C5346. doi:10.3390/s130405338

Badgley, C., Moghtader, J., Quintero, E., Zakem, E., Chappell, M.J., Aviles-Vazquez, K., Samulon, A., and Perfecto, I., 2007. Organic agriculture and the global food supply. Renewable agriculture and food systems 22, no. 2, 86-108.

Barclay, J.E., G. Leigh, J., 2000. Nitrogen Fixation. In Ullmann’s Encyclopedia of Industrial Chemistry. Wiley-VCH Verlag GmbH \& Co. KGaA. http://onlinelibrary.wiley.com/doi/10.1002/14356007.a17 471/abstract.

Branker, K., Pathak M.J.M., Pearce J.M., 2011. A Review of Solar Photovoltaic Levelized Cost of Electricity. Renewable and Sustainable Energy Reviews, 15, 4470-4482.

Brentrup, F., Küsters, J., Lammel, J., Barraclough, P., Kuhlmann, H., 2004. Environmental impact assessment of agricultural production systems using the life cycle assessment (LCA) methodology II. The application to $\mathrm{N}$ fertilizer use in winter wheat production systems. European Journal of Agronomy, 20(3), 265-279.

Camberato, J., Nielsen, B., Corn Stalk Nitrate Test "C Research and Recommendation Update. http://www.agry.purdue.edu/ext/soilfertility/news/cornstalknitrate.pdf

Camberato, J., Nielsen, R.L., Nitrogen Management Guidelines for Corn in Indiana. http://www.agry.purdue.edu/ext/corn/news/timeless/nitrogenmgmt.pdf 
Preprint of: Z. Du, D. Denkenberger, J.M. Pearce, Solar photovoltaic powered on-site ammonia production for nitrogen fertilization, Solar Energy 122, 562568 (2015). http://dx.doi.org/10.1016/j.solener.2015.09.035

Dinesh, H., Pearce, J.M., 2015. The Potential of Agrivoltaic Systems. (To be published)

Drinkwater, L.E., Wagoner, P., Sarrantonio, M., 1998. Legume-based cropping systems have reduced carbon and nitrogen losses. Nature 396, $262{ }^{*} \mathrm{C} 265$.

El-Fadel, M., Chedid, R., Zeinati, M., Hmaidan, W., 2003. Mitigating energy-related GHG emissions through renewable energy. Renewable Energy, 28(8), 1257“C1276.

Facanha, C., Horvath, A., 2007. Evaluation of life-cycle air emission factors of freight transportation. Environmental Science \& Technology, 41(20), 7138-7144.

Fernández, F.G., Nafziger, E.D., Ebelhar, S.A., Hoeft, R.G., 2012. Managing Nitrogen. In Illinois agronomy handbook. Crop science extension \& outreach, UIUC. Available at: http://extension.cropsciences.illinois.edu/handbook/

Flavin, C., 1990. Slowing Global Warming, Environmental Science \& Technology 24(2), 170-171.

FS-Curtis, SE Series Rotary Screw Air Compressors. http://cdn2.hubspot.net/hub/353230/file603889909-pdf/SE 20-50 Brochure Final \%281\%29.pdf?t=1427461099889

Goering, B. K. Ph.D. Dissertation, Cornell University, 1995.

Goetzberger, A., Zastrow, A., 1982. On the Coexistence of Solar-Energy Conversion and Plant Cultivation. International Journal of Solar Energy 1, no. 1 (January 1, 1982): pp.55“C69.

Granovskii, M., Dincer, I., Rosen, M., 2007. Greenhouse gas emissions reduction by use of wind and solar energies for hydrogen and electricity production: Economic factors. International Journal of Hydrogen Energy, 32(8), 927“C931.

Havlin, J.L., Kissel, D.E., Maddux, L.D., Claassen, M.M., Long, J.H., 1990. Crop rotation and tillage effects on soil organic carbon and nitrogen. Soil Science Society of America Journal, 54(2), 448-452.

Horvath, A., 2006. Environmental Assessment of Freight Transportation in the US (11 pp). The International Journal of Life Cycle Assessment, 11(4), 229-239. 
Preprint of: Z. Du, D. Denkenberger, J.M. Pearce, Solar photovoltaic powered on-site ammonia production for nitrogen fertilization, Solar Energy 122, 562568 (2015). http://dx.doi.org/10.1016/j.solener.2015.09.035

I.G.S. Generon, Nitrogen Generators Skidded Systems. http://igs-global.com/uploads/N2-MembraneSkidded-Systems.pdf

Ivy, J., 2004. Summary of Electrolytic Hydrogen Production, NREL. http://www.nrel.gov/docs/fy04osti/36734.pdf

Kitano, M., Inoue, Y., Yamazaki, Y., Hayashi, F., Kanbara, S., Matsuishi, S., Yokoyama, T., Kim, S.-W., Hara, M., Hosono, H., 2012. Ammonia synthesis using a stable electride as an electron donor and reversible hydrogen store. Nat Chem 4, 934"C940. doi:10.1038/nchem.1476

Licht, S., Wang, B., Mukerji, S., Soga, T., Umeno, M., Tributsch, H., 2001. Over 18\% solar energy conversion to generation of hydrogen fuel; theory and experiment for efficient solar water splitting. International Journal of Hydrogen Energy 26, 653“C659. doi:10.1016/S0360-3199(00)00133-6

Lovell, P.F., 1981. Heterogeneous catalysis in practice by Charles N. Satterfield, McGraw-Hill Company, May 1980; 416 pages; \$26.95. AIChE J. 27, 316“C316. doi:10.1002/aic.690270223

MacDonald, J.M., Korb, P., Hoppe, R.A., 2013. Farm size and the organization of U.S. crop farming. Economic Research Report Number 152, August, U.S.D.A. Economic Research Service. http://www.ers.usda.gov/media/1156726/err152.pdf

Marrou, H., Wéry, J., Dufour, L., Dupraz, C., 2013. Productivity and radiation use efficiency of lettuces grown in the partial shade of photovoltaic panels. European Journal of Agronomy, 44, 54-66.

Pearce, J.M., 2002. Photovoltaics; ${ }^{a}$ a path to sustainable futures. Futures, 34(7), 663-674.

Pearce, J.M., Johnson, S.J., Grant, G.B., 2007. 3D-mapping optimization of embodied energy of transportation. Resources, conservation and recycling, 51(2), 435-453.

Power, J.F., Schepers, J.S., 1989. Nitrate Contamination of Groundwater in North America. Agriculture, Ecosystems \& Environment, Effects of Agriculture on Groundwater, 26 (3"C4): 165“C87. doi:10.1016/0167-8809(89)90012-1.

Ribaudo, M., Livingston, M., Williamson, J., 2012. Nitrogen management on U.S. corn acres, 2001010. U.S.D.A. Economic Research Service. http://www.ers.usda.gov/media/947769/eb20.pdf 
Preprint of: Z. Du, D. Denkenberger, J.M. Pearce, Solar photovoltaic powered on-site ammonia production for nitrogen fertilization, Solar Energy 122, 562568 (2015). http://dx.doi.org/10.1016/j.solener.2015.09.035

Schelly, C., 2014a. Residential Solar Electricity Adoption: What Motivates, and What Matters? A Case Study of Early Adopters. Energy Research and Social Science 2, 183-191.

Schelly, C., 2014b. Transitioning to Renewable Sources of Electricity: Motivations, Policy, and Potential. Pages 62-72 in Controversies in Science and Technology, Volume 4. Edited by Daniel Lee Kleinman, Karen Cloud-Hansen, and Jo Handelsman. New York: Oxford University Press.

Schlögl, R., 2003. Catalytic Synthesis of Ammonia; ${ }^{\mathrm{a} A}$ 'Never-Ending Story’?. Angewandte Chemie International Edition 42 (18): 2004"C8. doi:10.1002/anie.200301553.

Shapiro, C.A., Ferguson, R.B., Hergert, G.W., Wortmann, C.S., Walters, D.T., 2008. Fertilizer Suggestions for Corn, Nebraska Extension. http://ianrpubs.unl.edu/live/ec117/build/ec117.pdf

Sims, R.E.H., 2004. Renewable energy: a response to climate change. Solar Energy, 76(1-3), 9“C17.

Steinberg, M., 1999. Fossil Fuel Decarbonization Technology for Mitigating Global Warming, International Journal of Hydrogen Energy 24, no. 8 (August 1999): pp.771“'C77.

Stern, N.H., 2006. Stern Review: The economics of climate change (Vol. 30). London: HM treasury.

Tesla. PowerWall.2015. Available at: http://www.teslamotors.com/powerwall

Tsoutsos, T., Papadopoulou, E., Katsiri, A., Papadopoulos, A.M., 2008. Supporting schemes for renewable energy sources and their impact on reducing the emissions of greenhouse gases in Greece. Renewable and Sustainable Energy Reviews, 12(7), 1767"C1788.

U.S.D.A., 2013, Table 2-U.S. plant nutrient use by corn, soybeans, cotton, and wheat, 1964-2012, available at: http://www.ers.usda.gov/data-products/fertilizer-use-and-price.aspx

U.S. Environmental Protection Agency, 2009. Technical Support Document for the Ammonia Production Sector: Proposed Rule for Mandatory Reporting of Greenhouse Gases, January 2009.

Wijnen, B., Anzalone, G.C., Pearce, J.M., 2014. Open-source mobile water quality testing platform. J 
Preprint of: Z. Du, D. Denkenberger, J.M. Pearce, Solar photovoltaic powered on-site ammonia production for nitrogen fertilization, Solar Energy 122, 562568 (2015). http://dx.doi.org/10.1016/j.solener.2015.09.035

Water Sanit Hyg Dev. 2014;4: 532. doi:10.2166/washdev.2014.137

Wittbrodt, B.T., Squires, D.A., Walbeck, J., Campbell, E., Campbell, W.H., Pearce, J.M., 2015. Opensource Photometric System for Enzymatic Nitrate Quantification, PLoS ONE 10(8): e0134989. doi: 10.1371/journal.pone.0134989 